DOI: 10.20472/BMC.2018.007.004

ARISSA SA-ARDNAK

Faculty of Management Science Silpakorn University, Petchaburi IT Campus, Thailand

\title{
FACTORS INFLUENCING THE ACCEPTANCE OF INTERNET PAYMENT SERVICES FOR ONLINE BUSINESS
}

\begin{abstract}
:
This quantitative research, which consisted of survey research, aimed to investigate the factors affecting the acceptance of an Internet payment service for online business using questionnaires collected from 100 entrepreneurs and 145 online consumers. The reliability coefficient of the questionnaires equaled 0.929 . The statistics used in this research consisted of frequencies, percentages, mean values, standard deviations, and t-tests. This research involved one-way ANOVA analysis and multiple regression analysis.

The research findings revealed that visibility (X3) and result demonstrability (X5) affected the acceptance of the Internet payment service by online entrepreneurs $(Y)$ at a statistical significance level of 0.05 , with the prediction equation of $Y=(0.803)+0.297 X 3+0.569 \times 5$. Relative advantages $(\mathrm{X} 1)$, visibility (X3), and result demonstrability (X5) affected the acceptance of an Internet payment service by online consumers $(Y)$ at a statistical significance level of 0.05 , with the prediction equation of $Y=(0.799)+0.335 X 1+0.305 \times 3+0.523 \times 5$.

Thus, entrepreneurs should consider the relative advantages of an Internet payment service for online business to meet consumer needs.
\end{abstract}

\section{Keywords:}

Business, Online, Internet Payment, Acceptance 


\section{Introduction}

Exponential business growth in the Thailand 4.0 Era requires technological and innovational development for driving the economy, including the Internet, the Internet of Things (IOT), or artificial intelligence (Al). For example, Amazon Business uses an open innovation model, where suppliers are allowed to sell products on its website and to rent servers which it has made a huge investment in, which aims to reduce business costs and generate more income (Ratchani Siwatthanachai, 2017)

State-of-the-art technology and innovation is subject to constant changes. Entrepreneurs who wish to be successful in conducting digital business need to rely on the Internet network in order to communicate with their customers, suppliers, partners, employees, and organizations to optimize organizational performance and competitiveness. In addition, operating a business under the Internet network will increase the opportunities for expanding distribution channels to customers across the world (Rungratsamee Boondao, 2016: 134).

Entrepreneurs can diversify their online channels, such as websites, applications, and social media, which help them to continuously reach consumers easily and penetrate their target groups. Social media is the main medium for advertising and public relations, which involves low cost compared with other media, such as television and banners. Thus, to do online business, it is necessary for them to expand their customer base, communicate with customers continuously, and expand their business base (Electronic Transactions Development Agency (Public Organization), ETDA, Ministry of Digital Economy and Society, 2017: 27).

E-commerce and e-business require new payment systems which support entrepreneurs' online business operations and satisfy consumers (Abrazhevich, D., 2001: 81-90). Epayment has become a popular transaction method due to increased convenience in usage of mobile phones and economic benefits resulting from reduced costs (Arvidsson, N., 2014: 150-170). By year 2013-2016, Internet payments have increased over the past 4 years ( Bank of Thailand, 2018). Users are aware of the importance of internet payments. But this type of payment is still not popular with consumers.

Internet payment is the payment for goods and services or transfer of funds via the Internet, in which customers can choose different payment methods, such as direct debit via a bank's Internet Banking system (similar to funds transfer) linked to online store websites, credit or debit card payment via a store's website, and e-Money payment via a store's website. To use e-Money, customers just open an account with an e-Money provider via its website and recharge money to the account (The Financial Consumer Protection Center, Bank of Thailand, 2018). 
User acceptance plays a significant role in the success and efficiency in business operations, so it is necessary to assess user acceptance of e-service technology (Taherdoost, H., 2018: 173-197) and the comprehensiveness of relevant technology. User experience in using the Internet for financial activities mostly influences their intention to use an e-payment service (Su, P., 2018: 186-197).

The author was interested in investigating the factors influencing the acceptance of an Internet payment service for online business among entrepreneurs and consumers in order to gain a better understanding about their problems and perspectives of choosing an Internet payment service.

\subsection{Research Objective}

To study the factors influencing the acceptance of an Internet payment service for online business.

\subsection{Research Methodology}

1) Investigating factors influencing the acceptance of an Internet payment service for online business by entrepreneurs and consumers, by designing quantitative research methods using a questionnaire as a tool for collecting data for analysis. The questionnaire consisted of four parts, as follows:

Part 1: Demographics, i.e. gender, age, education level, occupation, and monthly income.

Part 2: Opinions about the acceptance of an Internet payment service for online business, which comprised open-ended questions and multiple-choice questions, using the fivepoint Likert scale.

Questions in Part 2 consisted of five factors, i.e.

1) Relative advantage consisted of 4 subqueries.

2) End of use consisted of 5 subqueries.

3) Visibility consisted of 4 subqueries.

4) Compatibility consisted of 3 subqueries.

5) Result demonstrability consisted of 4 subqueries. 
There were three questions pertaining to the decision to use an Internet payment service, as follows:

1) Acceptance and decision-making to use an Internet payment service.

2) Decision-making to repeat the use of an Internet payment service.

3) Recommendation for the use of an Internet payment service to other people.

Part 3: Behavior of using an Internet payment service by entrepreneurs and consumers included: 1) Most common Internet payment service, 2) Most widely considered marketing mix factors, 3) Most benefits associated with using an Internet payment service, 4) Value that influences the decision-making to use an Internet payment service, and 5) People involved in the decision-making to use an Internet payment service.

Part 4: Open-ended questions about additional suggestions on the painpoints from their experience in using Internet payment service.

2) The population and samples in this research consisted of online entrepreneurs and consumers. Because the population was unknown, it was calculated using the formulas developed by Joseph Hair, Rolph Anderson, Bill Black, and Barry Babin (2010: 173). Normally, a multiple regression analysis requires at least 50 samples, but 100 samples for research is preferred. The minimum ratio of the number of questionnaires to independent variables should be 15: 1 or $20: 1$, which should vary according to the number of independent variables. As this research used five independent variables, which were multiple regression, at least 100 samples was needed. In this research, questionnaires were collected from 100 online entrepreneurs and 145 consumers, with a reliability level of 95 percent and standard deviation not exceeding five percent. This research used convenience sampling.

\section{3) Research procedures}

3. 1 Conducing literature review to study conceptual frameworks, theories, and research findings from relevant books, journals and articles in order to establish issues and the conceptual framework for this research.

3.2) Drafting a questionnaire in line with the research objective - to study factors affecting the acceptance of an Internet payment service on online business, by taking into account the correctness, comprehensiveness, and completeness of content and language used in the questionnaire. 
3.3) Having experts validate the drafted questionnaire.

3.4) Trying out the questionnaire which was improved by the experts with 30 online entrepreneurs and analyzing its reliability using Cronbach's a Coefficient, which was found to equal 0.929 . As it was close to 1 , this indicated that it had high reliability.

3.5) Utilizing the questionnaire which was completely checked for validity and reliability to collect online data from 100 online entrepreneurs and 145 online consumers, from 1 November 2017 to 31 January 2018.

4) Data Analysis

4.1) Descriptive analysis - The author validated the data and analyzed it using SPSS (Statistical Package for the Social Sciences) for the demographic data. The statistics used consisted of percentages, mean values, standard deviations, and t-test. One-way ANOVA and multiple regression analysis were conducted to test the hypothesis.

4.2) Interpretation of the mean values of the opinion levels using Fisher's guidelines (cited in Chatchavan Ruengpraprapan, 1996: 15), consisting of 1) 4.21-5.00 points: Highest, 2) 3.41-4.20 points: High, 3) 2.61-3.40 points: Moderate; 4) 1.81-2.60 points: Low; 5) 1.00-1.80 points, Lowest.

\section{Data Analysis}

Concerning demographics of the entrepreneurs, most of them were females (78. 6 percent), were 31-40 years old ( 57.1 percent), held an undergraduate degree ( 57.1 percent), and earned an average monthly income ranging between 20,001 and 30,000 baht (35.7 percent).

Their overall opinions about the acceptance of an Internet payment service for online business were at the highest level, with a mean value of 4.35 . The four factors that earned the highest level of opinions consisted of relative advantages, visibility, compatibility, and result demonstrability, with mean values of $4.48,4.36,4.38$ and 4.46 , respectively. Their opinions about the ease of use were at a high level, with a mean value of 4.12 .

The overall opinions of the entrepreneurs about their decision-making to use Internet payment service were at the highest level, with a mean value of 4.50 . In addition, their opinions about decision-making in choosing Internet payment service for three items 
were at a high level: 1) Acceptance and decision-making to use Internet payment service, 2) Decision-making to repeat the use of Internet payment service, and 3) Recommendation of the use of an Internet payment service to other people. The opinions about these three items were at the highest level, with mean values of $4.46,4.50$ and 4.45 , respectively.

The factors that made the entrepreneurs choose to use Internet payment service for online business consisted of: Direct debit via a bank's Internet banking service linked to an online store website ( 59.5 percent), distribution channels ( 50 percent), benefit for business operations ( 54.8 percent), high use statistics ( 61.9 percent), and dealers' participation in decision-making about the use of an Internet payment service for online business (38.1 percent).

Table 1. The Multiple Regression Analysis of Acceptance of Internet Payment Services on Online Businesses of Entrepreneurs.

\begin{tabular}{|l|c|c|c|}
\hline $\begin{array}{l}\text { Factors Influencing the Acceptance of } \\
\text { Internet Payment Services for Online } \\
\text { Business of Entrepreneurs. }\end{array}$ & B & S.E. & Beta \\
\hline Visibility $\left(\mathrm{X}_{3}\right)$ & 0.297 & .100 & .421 \\
\hline \multicolumn{2}{|c|}{0.569} & .121 & .521 \\
\hline \multicolumn{2}{|c|}{$\mathrm{R}^{2}=0.730$ SEE $=0.271 \quad \mathrm{~F}=56.333$} \\
\hline
\end{tabular}

${ }^{*}$ a statistical significance level of 0.05

As seen in Table 1, the multiple regression analysis revealed that all the three independent variables co-explained the variance of the entrepreneurs' acceptance of an Internet payment service for online business at 73 percent. The factors that influenced the acceptance of an Internet payment service for online business of the entrepreneurs $(\mathrm{Y})$ consisted of visibility $\left(\mathrm{X}_{3}\right)$ and result demonstrability $\left(\mathrm{X}_{5}\right)$ at a statistical significance level of 0.05 , with the prediction equation of $Y=(0.803)+0.297 X_{3}+0.569 X_{5}$.

With regard to the demographics of the online customers, most of them were females ( 81 percent), were 21-30 years old (61 percent), held an undergraduate degree ( 80 percent), and were students (52 percent), and earned an average monthly income less than 10,001 baht (48 percent). 
Overall, the online customers' opinions about the acceptance of an Internet payment service for online business were at the highest level, with a mean value of 4.27. Their opinions concerning the four factors: relative advantages, visibility, compatibility, and result demonstrability, were at the highest level, with mean values of $4.48,4.27,4.35$, and 4.29 , respectively. However, their opinions about the ease of use were at a high level, with a mean value of 3.59 .

Overall, the customers' opinions about their decision-making to use Internet payment service were at the highest level, with a mean value of 4.24. Their opinions about decision-making to use Internet payment service for two items were at the highest level: 1) Acceptance and decision-making to use Internet payment service and 2) Decisionmaking to repeat the use of Internet payment service, with mean values of 4.30 and 4.28, respectively. Their opinions about Item 3) Recommendation for the use of an Internet payment service to other people, were at a high level, with a mean value of 4.16 .

The most common behaviors of the online consumers concerning the use of an Internet payment service for online business consisted of direct debit via the Internet Banking of banks linked to online store websites ( 53 percent). The factors that influenced their decision-making for using Internet payment service the most consisted of price ( 45 percent), benefit for financial transactions ( 37 percent), and high use statistics of an Internet payment service (54 percent). For them, their friends influenced their decisionmaking about the use of an Internet payment service for online business (40 percent).

Table 2. The Multiple Regression Analysis of Acceptance of Internet Payment Services on Online Businesses of Consumers.

\begin{tabular}{|l|c|c|c|}
\hline $\begin{array}{c}\text { Factors Influencing the Acceptance of } \\
\text { Internet Payment Services for Online } \\
\text { Business of Consumers. }\end{array}$ & B & S.E. & Beta \\
\hline Relative advantages $\left(\mathrm{X}_{1}\right)$ & 0.335 & .107 & .422 \\
\hline Visibility $\left(\mathrm{X}_{3}\right)$ & 0.305 & .099 & .239 \\
\hline Result demonstrability $\left(\mathrm{X}_{5}\right)$ & 0.523 & .105 & .237 \\
\hline \multicolumn{2}{|c|}{$\mathrm{R}^{2}=0.662$ SEE $=0.436 \mathrm{~F}=94.858$} \\
\hline
\end{tabular}

*a statistical significance level of 0.05

As shown in Table 2, the multiple regression analysis revealed that all of the three independent variables co-explained the variance of the consumers' acceptance of an Internet payment service for online business at 66.2 percent. The factors that influenced 
the acceptance of an Internet payment service for online business of the consumers $(Y)$ comprised relative advantages $\left(X_{1}\right)$, visibility $\left(X_{3}\right)$, and result demonstrability $\left(X_{5}\right)$ at a statistical significance level of 0.05 , with the prediction equation of $Y=(0.799)+0.335 X_{1}$ $+0.305 X_{3}+0.523 X_{5}$.

\section{Conclusions and Discussion}

The research findings revealed that the behavior of using Internet payment service for online business that influenced the decision-making of the entrepreneurs and consumers the same was direct debit via banks' Internet banking service linked to online store websites because the service was convenient and fast. Funds transfer service is processed within seconds, without a need for providing any details, and data is automatically sent to the system.

As for the marketing-mix factors, the entrepreneurs paid attention to the sales channels of an Internet payment service for online business because they needed to provide a service that met consumer needs. Availability of diverse sales channels provided Internet payment service options for consumers (who were price-oriented) to choose from in accordance with their needs. The customers decided to opt for an Internet payment service in which they paid no fee or the lowest rate of fee. As online business involved numerous customers, this was in line with the fact that the entrepreneurs attached great importance to sales channels with Internet payment service. This is consistent with the research by Saowanit Udomvechsakul (2014), which studied factors affecting the confidence in using the M-Banking Application among service users in Bangkok and its peripheral provinces. It found that the price factor was consistent with the acceptance of the service. This finding is also in line with the study by Achaporn Kwangsawad and Patcharaporn Chaipattanamatee (2013: 68) entitled "The Factor to Accomplish the Affiliate Marketing for Internet Entrepreneurs: a Preparation to AEC". The study found that the availability of a variety of commission payment channels was the most important factor that influenced Internet entrepreneurs' choosing of affiliate marketing partners, followed by the minimum amount of commission.

The decision to use Internet payment service for online business by both entrepreneurs and consumers gave a high priority to high use statistics, since this demonstrated payment service use behaviors of the majority of people.

Dealers influenced the entrepreneurs' decision-making to use Internet an payment service for online business because dealers were compared to representatives voicing the needs of the majority of consumers, so the entrepreneurs did not need to ask 
individual consumers about their needs. On the consumer side, friends influence such decision-making, because of the fact that most of the consumers who were the respondents were 21-30 years old, who were late adolescents. Adolescents have connections with their friends more than any other age group. Accordingly, the online consumers trusted and were more likely to agree with their friends' ideas so that they were accepted within their peer group. This is in line with the study by Jiyada Kaewtan (2015: 58), which investigated factors that influenced the acceptance of e-payment service via smartphone, with a case study involving Bangkok and Pathum Thani. The study found that the reference group was at a high level, whereby friends or acquaintances had an influence on the use of e-payment service via smartphone at the highest average. This is also consistent with the research by Chawisa Phumdontree (2017: 75), which investigated factors that affected the acceptance of PromptPay use of the study's population in Bangkok and its peripheral provinces. It revealed that influential, admired, respected, and surrounding persons had influence on the acceptance of PromptPay use.

The factors that similarly affected the acceptance of Internet payment service for online business of these online entrepreneurs and consumers comprised visibility $\left(X_{3}\right)$ and result demonstrability $\left(X_{5}\right)$. The visibility of Internet payment service for online business comprised benefits and good value for money, validity, auditability, reduction in payment transaction cost, reduction in procedures, and high speed service. As for result demonstrability of Internet payment service for online business, it dealt with an increase in payment channels, its popularity, being recommended to other people, and being recognized as trendy people. Nonetheless, the factors that differently affected the acceptance of Internet payment service for online business between these two groups consisted of relative advantages $\left(X_{1}\right)$ since the online consumers focused on convenience, ease of use, 24/7 service availability, as well as time- and place-unlimited service availability, so long as Internet connection is available. The online entrepreneurs took into account what customers liked and focused on the end result of consumers' use of Internet payment service for online business. This allowed them to know customer needs and levels of customer satisfaction, which then leads to the development of Internet payment service for online business to yield maximum efficiency and effectiveness. This is in line with the theory developed by Moore, G.C., and Benbasat, I. (1996 : 132-146), who mentioned that the acceptance and use of innovations were influenced by various factors, i.e. the ease of use, relative advantages, compatibility, result demonstrability, visibility, and trial ability. 


\section{Suggestions}

1) Entrepreneurs should take into account relative advantages of the acceptance of Internet payment service for online business in response to online consumer demand.

2) Entrepreneurs should promote marketing of price of Internet payment service for online business to attract customers to Internet payment service.

3) Entrepreneurs should take into high use statistics because it has an influence on the decision-making to choose Internet payment service for online business.

4) Targeted penetration should be considered consumers friend and dealers because they are influence the decision-making to use Internet payment service for online business among adolescent consumers and entrepreneurs.

\section{Suggestions for future research}

1) Future research should be qualitative research with in-depth interviews with entrepreneurs and consumers to analyze the needs of individual entrepreneurs and consumers.

2) There should be continuous research because business and consumer behavior are constantly changing.

\section{References}

Abrazhevich, D. (2001). Classification and characteristics of electronic payment systems. Proceeding of 2nd International Conference on Electronic Commerce and Web Technologies, EC-Web 2001; Munich; Germany; 4 September 2001 through 6 September 2001. 2115, 81-90.

Achaporn Kwangsawad and Patcharaporn Chaipattanamatee. (2013). Factor to Accomplish the Affiliate Marketing for Internet Entrepreneur : a preparation to AEC. Rajamangala University Of Technology Rattanakosin.

Arvidsson, N. (2014). Consumer attitudes on mobile payment services - results from a proof of concept test. International Journal of Bank Marketing, 32(2), 150-170.

Bank of Thailand. (2018). Statistical reports of electronic payment of equipment or via the internet. Bangkok : Bank of Thailand. 
Chatchavan Ruengpraprapan. (1996). Basic Statistics. KhonKaen : Klungnana Vitthaya Press.

Chawisa Phumdontree. ( 2017 ). Factors affecting to consumer confidence in promptpay fund transfer service in The Bangkok Metropolitan area. Master of Business Administration's Independent Study, faculty of Commerce and Accountancy, Thammasat university.

Electronic Transactions Development Agency (Public Organization), ETDA, Ministry of Digital Economy and Society. (2017). Value of e-Commerce Survey in Thailand 2017. Bangkok : Electronic Transactions Development Agency (Public Organization), ETDA, Ministry of Digital Economy and Society.

Jiyada Kaewtan. (2015). Factors influencing the acceptance of electronic payment using smartphone devices : in case of Bangkok and Pathum Thani. Master of Business Administration's Independent Study, Rajamangala University Of Technology Rattanakosin.

Joseph Hair, Rolph Anderson, Bill Black, and Barry Babin. (2010). Multivariate Data Analysis (7th Edition). Harlow, United Kingdom.

Moore, G.C., and Benbasat, I. (1996). Integrating Diffusion of Innovations and Theory of Reasoned Action Models to Predict Utilization of Information Technology by End-Users, in K. Kautz and J. Pries-Heje (Eds.) Diffusion and Adoption of Information Technology, Chapman and Hall, London.

Ratchani Siwatthanachai. (2 017 ). World Innovation Trends Go to Social Technology. Posttoday: The Bangkok post plc. (October 20, 2017).

Rungratsamee Boondao. (2016). Information System for Managing Business in the Digital Age. Nonthaburi : Lucky Book.

Saowanit Udomvechsakul. (2014). Factors affecting to consumer confidence in M-Banking Appliation in Bangkok Metropolitan region. Master of Business Administration's Independent Study, faculty of Commerce and Accountancy, Thammasat university.

Su, P. (2018). How users' Internet experience affects the adoption of mobile payment: a mediation model. Technology Analysis and Strategic Management, 30(2), 186-197.

Taherdoost, H. (2018). Development of an adoption model to assess user acceptance of e-service technology: E-Service Technology Acceptance Model. Behaviour and Information Technology, 37( 2), 173-197.

The Financial Consumer Protection Center, Bank of Thailand. (2018). Internet Payment. Bangkok : The Financial Consumer Protection Center, Bank of Thailand. 